\title{
CORRESPONDENCE
}

\section{Pragmatic Democracy and Constitutional Government: Comments on Robert Eden*}

\section{ELDON J. EISENACH}

The University of Tulsa

The thesis of Robert Eden's paper is simply stated. Franklin Roosevelt's "Commonwealth Club Address" appropriated "the rhetoric of formal liberal constitutionalism" and made it available as a political resource for "a pragmatic liberal president" (p. 75; see p. 139). There is much to recommend this thesis. Recent writings in constitutional law and political theory ask whether, for the past sixty years, we have been functioning outside the constitution or, more broadly, outside any philosophically defensible system of political ideas. And recent studies of the modern presidency require that the analysts generate vocabularies quite outside traditional constitutional language in order to describe the institutional position and practices of the presidency. ${ }^{1}$ Eden insists that if we look carefully at the stages of composition of one of Franklin Roosevelt's major campaign addresses we can witness at the creation both the subversion of formal liberal constitutionalism and its reappropriation in the form of individual rights (largely economic) now underwritten by executive power and administrative will (p. 108). What he makes of this new combination, however, is somewhat ambiguous. Suffice it to say first that Eden portrays it as both a subversion of "classical" liberalism (and Americanism) represented by eighteenth-century constitutionalism (pp. 126-128) and the appropriation of that liberalism, but now revealed in its true Hobbesian form as

*Robert Eden, "Pragmatic Liberalism: John Dewey, Adolf A. Berle, and FDR's Commonwealth Club Address of 1932," Studies in American Political Development, 7, (1993): 74150. An earlier version of this paper was given at the Annual Meeting of the American Political Science Association, Washington, D.C., September 2-5, 1993, Claremont Institute Panels.

1. Jeffrey Tulis, The Rhetorical Presidency (Princeton: Princeton University Press, 1987); Theodore Lowi, The Personal President (Ithaca: Cornell University Press, 1985); Ryan Barilleaux, The Post-Modern Presidency (Westport, CT: Greenwood Press, 1988). 
desire, power, and will (pp. 134-142, 145-147). On this latter reading the New Deal is a perverse fulfillment of the liberal founding of America. The comments which follow are preface to these alternative understandings in the paper, a critique of Eden's narrative of the history of American political thought, and the outline of another narrative which more closely integrates our political thought with our political history.

\section{THE ANTIFORMALISM OF PRAGMATISM AND PROGRESSIVISM}

The chief virtue of the paper is that it recognizes and adumbrates the antiformalism of both progressive political theory and the philosophy of pragmatism. This antiformalism, shaped within a social-evolutionary theory of history and human development, took many forms. The most obvious was its rejection of "dualism," whether in the form of individual vs. society, private vs. public, rights vs. duties, or local vs. national. Constitutionalism read as fixed sets of boundaries, procedures, and jurisdictions was the most obvious example of formal, mechanistic, and abstract thinking which permeated our social, economic, and political ideas. The mantra of the progressives was interdependence, and the fulfillment of their vision (and of history itself) was connectedness and community. ${ }^{2}$

Eden, however, might better have reached back into the late nineteenth and early twentieth century to find much earlier and stronger evidence of this antiformalism in its first articulations. Neither Dewey nor Berle was saying much new in the 1920s when they attacked abstract individual rights, "mechanical jurisprudence," and formal-legal understandings of our political and economic life. In the writings of social gospel churchmen and political economists and sociologists-it is often hard to tell them apart - the ground was thoroughly prepared for what came to be known only much later as "pragmatism" and attached to the New Deal. Here is a sampling. The first is by a colleague of Dewey's at Michigan, Charles Horton Cooley, in a college textbook in continuous use for twenty years (1909-1929) but (as textbooks do) expressing ideas developed much earlier:

Formalism goes very naturally with sensuality, avarice, selfish ambition, and other traits of disorganization, because the merely formal institution does not enlist and discipline the soul of the individual, but takes hold of him by the outside. . . . The lower "individualism" of our time, the ruthless self-assertion which is so conspicuous, for example, in business, is not something apart from our institutions but expresses the fact that they are largely formal and unhuman, not containing and enlarging the soul of the individual. ${ }^{3}$

Cooley's text repeated in the language of social psychology the ideas of political economists, sociologists, and social gospel theologians. A found$3-125$.

2. James Gilbert, Designing the Industrial State (Chicago: Quadrangle Books, 1972), pp.

3. Charles Horton Cooley, Social Organization: A Study of the Larger Mind (Glencoe, IL: Free Press, 1956, orig. 1909), p. 349. 
ing economist of the Wharton School listed as one of the ten principles of social Christianity "the doctrine of social responsibility, in contrast with individual rights." The Baptist theologian and ecumenical leader Samuel Zane Batten declared that "just so far as democracy means the enthronement of self-interest and the apotheosis of individual desire . . . so far it becomes an iniquitous and dangerous thing." 4

Formal liberal constitutionalism posited both strictly limited public power and clear divisions between federal and state powers. Progressive intellectuals and churchmen would have none of this. "Except the state is born again, except it be delivered from pagan doctrines of law and government ... [and] from merely individual theories of freedom, it cannot see the divine social kingdom. Herbert Croly wanted to free Americans from "the monarchy of the constitution," hoping that "the American nation [will] no longer be instructed as to its duty by the Law and the lawyers." We must replace law and its abstract "intellectualism" for a democratic faith grounded in pragmatism. ${ }^{5}$ E.A. Ross's textbook in sociology, in continuous use for more than thirty years (1901-1932), distinguished between "political" and "ethical" forms of social control. The former, operating through formal laws and sanctions, are required in a society whose population is marked by "antipathetic and jarring" elements, where economic and status divisions are growing and "in proportion as the parasitic relationship is maintained between races, classes and sexes." Ethical instruments of control, in contrast, rest on the informal mechanisms of public opinion. "Being more mild, enlightening, and suasive," these instruments are appropriate to societies in which "social contacts between all elements in the population are many and amicable" and where "the social constitution . . . conforms to common elementary notions of justice. In the words of Dewey's and Tufts's phenomenally successful ethics textbook (1908-1942), common ends not arrived at by "common, free voluntary cooperation in process of achievement" are common in name only, requiring "bribes of pleasure, threats of harm, use of force."6

In short, for more than forty years before the composition of the "Commonwealth Club Address," college students, northern middle-class church members, and readers of the new national monthlies were taught that formal legal-political institutions premised on democratic individualism were a barrier to the achievement of democracy and social justice. Against Eden's understanding, this reading of American political thought says that "antiformalism" was in the name of civic virtue and democratic (or Chris-

4. Simon Patten, quoted in Ronald White and Charles H. Hopkins, eds., The Social Gospel: Religion and Reform in Changing America (Philadelphia: Temple University Press, 1976), p. 133; Samuel Zane Batten, The Christian State; the State, Democracy and Christianity (Philadelphia: The Griffith and Rowland Press, 1909), p. 215.

5. George Herron, quoted from White and Hopkins, Social Gospel, p. 174; Herbert Croly, Progressive Democracy (New York: Macmillan, 1914), p. 210.

6. Edward Alsworth Ross, Social Control: A Survey of the Foundations of Order (New York: Macmillan, 1918), pp. 411-12; John Dewey and James Tufts, Ethics (New York: Henry Holt and Company, 1908), p. 304. 
tian) community and was posed as the alternative to entrapment in a Hobbesian world of passion and interest.

Even the notion of public opinion shared these antiformalist (and antiindividualist) features. Cooley's textbook rejects out of hand the notion that public opinion can ever be expressed as the "mere aggregate of separate individual judgments. . . . It may be as different from the sum of what the individual could have thought out in separation as a ship built by a hundred men is from a hundred boats each built by one man." 7 The Yale economist (and later president) Arthur Hadley was quite willing to discount "the fact that a majority may be willing to vote for a measure" as a test of authentic public sentiment. This vote, after all, "may be simply the outcome of widespread personal interest" and represent "opinions which a man is prepared to maintain at another's cost, but not at his own." Like Rousseau's general will, authentic public opinion literally constitutes individuals into citizens of one sovereign people,

represented by a common public sentiment which includes all good men, minorities as well as majorities, who support the government not as a selfish means for the promotion of their own interest, but as a common heritage which they accept as loyal members of a body politic, in a spirit which makes them ready to bear its burdens as well as to enjoy its benefits. ${ }^{8}$

Behind this rejection of formalism and the kinds of individualism it was said to foster was a religious nationalism most vividly expressed by Lincoln and the Republican party. To the progressives, America was both refounded and redeemed by the Civil War, only to suffer declension in the decades that followed. With the defeat of slavery and lingering notions of confederacy, the spiritual nation of America as New Israel finally became an authentically political nation. The covenant which the first colonists made and the Revolution restored was remade and restored under the leadership of "father Abraham" and his dedicated followers.

This cultural context of progressive public doctrine in its late-nineteenth-century origins left a paradoxical legacy when it became a powerful discourse in national party-electoral contexts. We had always cultivated and enforced civic virtue locally and through voluntary associations - what Webster called "free institutions." But a national civic republicanism was now a political project of the reformers and came face to face with a constitutional and party system which were structurally federated, limited, and liberal. With the exception of the Civil War period, where the national Republican party functioned informally as the centralized state, in the nineteenth century civic virtue could only find a home in the states and in local governments and voluntary associations. But these common goods were pluralistic and often contradictory. At first, through nationally based organizations and movements, reformers sought to impose common national ends across jurisdictions, proceeding city by city and

7. Cooley, Social Organization, p. 121.

8. Arthur Twining Hadley, The Education of the American Citizen (New York: Charles Scribner's Sons, 1901), pp. 25, 27, and 35. 
state by state. When, in the early twentieth century, progressive ideas and discourse were appropriated to expand the resources and powers of the national government while that government was still in the grip of constitutionalism and in the service of private interests and locally based party organizations, irony and misunderstanding necessarily follow. We are still suffering the political and philosophical consequences. The locus classicus of this irony and misunderstanding is Woodrow Wilson, both in his own writings and in how he is now understood.

\section{WOODROW WILSON AND THE SUBVERSION OF NATIONAL PROGRESSIVISM}

In charting the history of political ideas at the turn of the century through the New Deal there is often serious confusion between what progressives and early pragmatists meant by democracy and what we now call modern liberalism. Studies of "urban" (i.e., Catholic and working-class) and "southern" progressivism, for example, ${ }^{9}$ rob progressivism of any coherence whatever. ${ }^{10}$ Progressive intellectuals from the mid-1880s onwardi.e., almost half a century before the "Commonwealth Club Address"were, as I tried to show above, unabashed "liberal" bashers, if by liberal we mean a rights-based individualism grounded in external laws and neutral procedures. Their doctrines were shaped within the culture of evangelical Protestantism, abolitionism, and the notion of the Republican party as a party against parties. They were cosmopolitan, core-industrial, northern, prowomen, and messianically nationalist. They were as decidedly hostile to the ways of life of Wilson's marginal, backward, shopkeeping, macho, and southern-racist constituencies as they were to his own nostalgic clinging to the archaic language of individual rights and constitutionalism and his defense of party. Indeed, they saw his constitutionalism and his defense of party as the primary means by which those ways of life and their economic foundations were politically sustained. One need look no farther than Wilson's 1908 lecture on the U.S. Constitution. In the eyes of these progressive academics and publicists, Wilson just didn't get it. He clung to the anachronistic idea that "liberty belongs to the individual, or it does not exist" and that "liberty is the object of constitutional government" because "representatives of government have no authority except such as they derive from the law." Wilson was perforce forced to deny (until World War I) that America was an organic-historical nation, just now emerging into world history as a democratic empire. Wilson's formal liberal constitutionalism and his Democratic party affiliation forced him

9. John D. Buenker, Urban Liberalism and Progressive Reform (New York: Norton, 1978); David Sarasohn, The Party of Reform: Democrats in the Progressive Era (Jackson: University Press of Mississippi, 1989).

10. Daniel T. Rodgers, "In Search of Progressivism," Reviews in American History 10 (December, 1982), pp. 113-32, takes this as a truism. For an excellent summary of the differences between Theodore Roosevelt's New Nationalism and Woodrow Wilson's New Freedom, see Donald R. Brand, Corporatism and the Rule of Law (Ithaca: Cornell University Press, 1988), pp. 33-95. 


\section{4}

\section{ELDON J. EISENACH}

to deny this vision of the American future. "Are the United States a community?" he asked and was forced to reply, "in most things no." 11

[W] hen the several chief organs of government are separated by organic law and offset against each other in jealous seclusion, no common legal authority set over them, no necessary community of interest subsisting amongst them, no common origin or purpose dominating them, they must of necessity, if united at all, be united by pressure from without; and they must be united if government is to proceed. They cannot remain checked and balanced against one another; they must act, and act together. They must, therefore of their own will or of mere necessity obey an outside master. ${ }^{12}$

The only nationally unifying master outside constitutional limits and jurisdictions was party but there were two of them and Wilson's was radically decentralized and publicly committed to states' rights and constitutional literalism. As Wilson himself stated, both national parties were each a series of local and state confederations propelled by "the restless strain of contest and jealousy." Intraparty unity was usually not the product of a shared and substantive idea of public good but the necessary expedient for electoral victory. Wilson defended, in short, the antithesis of the progressive ideal of national citizenship. "The very compulsion of selfishness had made [parties] serviceable; the very play of self-interest has made them effective." Networks of party machines and bosses underwrite constitutional government and require patronage and bargains to keep "the several segments of parties together." To attack party bosses and machines is to subvert our form of constitutional government and individual liberty: "the disrepute in which professional politicians are held, is in spirit highly unconstitutional." 13

It is no wonder that progressive intellectuals did not consider Wilson a progressive at all and persistently accused him of bad faith. ${ }^{14}$ What he did was seek to sell some progressive governmental measures and programs on the grounds that they protected the "rights" of the little man and the states' rights of the backward and conservative regions of the country from the modernizing and cosmopolitan innovations of the core. The one exception to this was his appeal to northern industrial labor. But at this stage his appeal was an invitation to labor to join the marginals in the South and West to split industrial profits rather than to stay with the industrialists and seek to achieve ever-greater national productivity (and, with it, ever-greater regional disparities of wealth and power). Wilson's legalistic language expressed a culturally and economically defensive rhetoric which indulged the illusions of a rather hapless and helpless

11. Woodrow Wilson, Constitutional Government (New York: Columbia University Press, 1908), pp. 16, 18, 20, and 51.

12. Wilson, Constitutional Government, p. 211 , emphasis added.

13. Wilson, Constitutional Government, pp. 208-9.

14. Croly, Progressive Democracy, pp. 16-20, treats Wilson with the same contempt that he treated the Constitutional Unionists during the controversy over slavery. The ideas of both were built on massive contradictions. 
series of marginal constituencies mired in traditional values even as it brought the Democratic party to national victory in a three-way presidential contest. But for the contingency of war and, thus, the bringing of national progressives into effective power for an all-too-brief period, Wilson might well have despoiled the "overproducing" industrial North and agricultural Midwest to subsidize and thus resuscitate the dying world of tenant and subsistence farms, local monopoly rent, and inefficient and locally monopolistic main streets. It is no wonder that Charles Beard, the great analyst of this same logic in an earlier period, had so much respect for Hamilton and the Federalists and so little for the Antifederalists and Jefferson. And it is no wonder that Croly pictured Wilson as a kind of "dictator" (but a benign one) because each element of the party depended upon him for its own interests and not because he represented a common substantive vision (Croly 1914:335-46). And on this reading, too, Herbert Hoover's individualism, shaped in the civic republicanism of national service and national associational life, was so economically and culturally progressive while Wilson's was so economically and culturally conservative -at once locally democratic and constitutionally liberal. ${ }^{15}$

Against this background, I want to consider whether FDR's "Commonwealth Club Address" was, in Eden's words, "the most clear-sighted and radical statement of [the root] dilemma of pragmatic liberalism" (p. 78) or only another in a series of dodges and evasions begun by Wilson and necessitated when a nineteenth-century party of disparate marginals seeks to govern a nation whose material basis in the twentieth century was the product of the moral culture, talents, and energies of the northern Protestant core. Symbolically stated, I want to consider whether the final draft treatment of Wilson in that address was a bold new synthesis or a somewhat craven fiction to paper over the same contradictions which Wilson himself faced in 1912. Stated in terms of the history of ideas, the question is whether Berle's "translation [of] pragmatic philosophy of history into a Lockean political rhetoric" (p. 133) was a deep resolution or a superficial expedient.

\section{DEWEY'S VISION AND BERLE'S WILSON}

When the "Commonwealth Club Address" was being drafted, John Dewey was over seventy years old and a well-established institution in American life. His first essay outlining his vision of a democratic culture and society, "The Ethics of Democracy," was written in 1888. Berle was born in 1895 and began writing in the 1920s. By the 1920s, Dewey's politics and ideas had become increasingly remote from the world of effective power. In retrospect, his third-party alternative-a haven for so many disenchanted progressives-represented more a narcissism of impotent moral

15. Croly, Progressive Democracy, pp. 335-46; Philip Abbott, The Exemplary Presidency: Franklin D. Roosevelt and the American Political Tradition (Amherst: University of Massachusetts Press, 1990), pp. 29-38. 
superiority than a possible future. Eden, in effect, makes this same argument about Dewey (pp. 98-99), but neglects the fact that Dewey and his fellow progressive academics and intellectuals had gone from victory to triumphal victory from the 1880 s onward: in the colleges and universities, in the women's movement, in the new mass media, in the Protestant churches. State and municipal legislation from the 1890 s to 1915 is a stunning record of the political impact of these cultural and intellectual victories. ${ }^{16}$ In the 1920 s, however, disenchanted progressive intellectuals -i.e., those who did not become 1920s technocrats-increasingly were seen and saw themselves as public moralists/secular clergymen necessarily above the sordid play of the party-electoral games which the rest of the country continued to play. ${ }^{17}$ The New Republic under Herbert Croly became something of a wistful theological weekly in this period. We must remember that Dewey wrote the essays which became Individualism Old and New just a few years after Croly had outlined a mystical and vaguely Christian vision of progressive renewal for these same readers. ${ }^{18}$ When progressivism was at a dead end, its intellectual leaders demoralized, and its older and broadly based Protestant constituency hopelessly split by the fundamentalist controversy, what better to do than to recall the original vision of the Religion of America-albeit a vision no longer connected to real political forces? Eden recognizes both this "spiritualist" element and the distance Dewey seems to have from the immediate political-economic situation (pp. 88-92) but discounts their implications.

Adolph Berle, thirty-six years younger than Dewey, was an exemplary product of progressive culture. The best proof of this is Eden's summary (pp. 114-118) of Berle's first drafts of what became the "Commonwealth Club Address." Is there any doubt that Berle was intellectually closer to Hoover's associationalism than to Wilson's constitutional liberalism? According to Eden, Berle's early drafts of the "Commonwealth Club Address"-appropriately entitled "On Progressive Government"-were thoroughly grounded "upon historical social science and institutional economics," and Eden is surely right. But this social science and this economics were in turn profoundly shaped within a Hegelian and evangelical Christian framework by the very people who were Berle's intellectual and moral models: Simon Patten, Richard Ely, Henry Carter Adams, Franklin Giddings, E.R.A. Seligman, Albion Small, Charlotte Perkins Gilman, Jane Addams, and, of course, his own rather famous father. ${ }^{19}$ Note Berle's

16. Both Croly, Progressive Democracy, and Benjamin Parke De Witt, The Progressive Movement (New York: Macmillan, 1915), fairly burst with predictions of final victory.

17. Eden (p. 93, n. 64) beautifully captures this failure and this demoralization, quoting John Dewey, Middle Works 13 (Carbondale: Southern Illinois University Press, 1983), pp. 301-2.

18. Edward A. Stettner, Shaping Modern Liberalism; Herbert Croly and Progressive Thought (Lawrence: University Press of Kansas, 1993), pp. 144-57 ; and see Eden's summary, pp. 889, of Individualism Old and New for these same mystical cords in Dewey and on how far removed they were from current party-electoral discourse.

19. Adolph Berle, Sr., was a prominent Congregational churchmen who wrote exten- 
initial attempt to outline the defining images of Roosevelt's candidacy. He wanted to distance Roosevelt from Wilson and to connect him to Theodore Roosevelt, who had at least headed in the right direction (pp. 110113). The only virtue that Wilson had was as articulator of the primal and inchoate yearnings of Americans to fulfill their democratic destiny; his programs, however, were hopelessly backward looking and must be thoroughly repudiated (p. 119).

On this reading of Berle's initial attempt, FDR was to become a populist TR, Hoover a laissez-faire conservative Taft, ${ }^{20}$ and Wilson remain what he in fact was, a hopeless anachronism like William Jennings Bryan-that other famous liberal constitutionalist, "Jeffersonian socialist," and reformer manque. ${ }^{21}$ What Eden terms the "comical" mis-fit between Roosevelt the candidate and Berle's "feckless effort" (p. 116) in the early drafts did not result because Berle was writing as if his first choice, Newton Baker, had been chosen. The comedy and fecklessness are a tragic result of the radical asymmetry between Roosevelt's Democratic party coalition and coherent progressive ideas or, more broadly, between our constitutionally based political system and the emergent national cultural and economic systems. This, I think, is why Roosevelt was compelled to avoid "a public philosophy confrontation" (p. 111), and not because he was already foreshadowing a new liberalism premised on untrammeled executive action. No wonder that even in Berle's second draft, Wilson's only substantive virtue is his activist foreign policy, which required the coherent exercise of national authority in planning for postwar reconstruction. Wilson was smart enough to recognize that national sovereignty in central Europe must be underwritten by a powerful and authoritative international order-something his liberal constitutionalism and Democratic party loyalties blinded him to domestically regarding individual rights. This international planning dimension is, I think, why Berle concluded

sively for Bibliotheca Sacra (so did young John Dewey), a major organ of modernizing evangelical theology and the social gospel published first at Andover Seminary and then at Oberlin under a new sub-title: A Religious and Sociological Quarterly. See Bruce Kuklick, Churchmen and Philosophers: From Jonathan Edwards to John Dewey (New Haven: Yale University Press, 1985); and Louise L. Stevenson, Scholarly Means to Evangelical Ends: The New Haven Scholars and the Transformation of Higher Learning in America, 1830-1890 (Baltimore: Johns Hopkins University Press, 1986). Berle's father was the author of Christianity and the Social Rage (New York: McBride, Nast, 1914) which outlines the teachings of Christian Sociology in light of American social problems.

20. Herbert Croly got Taft-Hoover exactly right when he said that the Republican party, having sponsored an industrial-financial system outside the bounds of the Constitution, was now hopelessly trying to defend it on constitutional grounds of individual rights: "It built up a national economic system beyond the fortifications of the Constitution; but it wanted that system to enjoy both the privilege of unlimited expansion and the shelter of impregnable and definite walls." Croly, Progressive Democracy, p. 101.

21. Sarasohn, Democrats in the Progressize Era, shows how Bryan and his ideas still defined progressivism in much of the south and west in the early decades of the 20th century. Against Eden (pp. 117-8), Berle was not inconsistent when he ridiculed Wilson as an obsolete, nineteenth-century liberal; he was only repeating conventional progressive wisdom. See Croly, Progressive Democracy, pp. 16-20. 
that the nineteenth and twentieth century met and clashed in Wilson's soul.

We know from Eden how Wilson finally emerged in the "Commonwealth Club Address." In this final draft Wilson becomes the true prophet in warning of the dangers to freedom in America but, because of the war, failed to lead us down the only effective path to regain that freedom. In Eden's words, Wilson was only "a visionary of deeds . . not carried into action" (p. 121). By this means, FDR had his Wilson cake and Berle could eat it, too. But this final product looks more to me like a series of tactical retreats by Berle rather than a grand synthesis. Berle, the corporate lawyer and legal reformer, was used to this kind of mediation. He helped rethink and reshape the law of corporate property, corporate finance, and internal corporate governance in the $1920 \mathrm{~s}$ and 1930s. His Modern Corporation and Private Property (1932) was read by the new generation of law professors and corporate lawyers not as a muckraking exposé which it never was, but as an examination of the legal and economic consequences of the division between titular ownership and actual control of publicly held corporations. By the mid-1950s, far from being a mouthpiece for the emerging plebiscitary and rhetorical presidency, Berle wrote in praise of the international (read Anglo-American) oil cartel as the embryonic world government, a prophetic "City of God" on earth. ${ }^{22}$ Like his father and his progressive forebears, Berle ultimately placed much more trust in the spontaneous activity of "private governments" and other free institutions than in public and official ones, especially those dominated by electoral parties and aggregations of private interests. At best, constitutional forms and the mantel of law should be the capstone of ideas and actions and forces outside themselves and must always be prepared to give way to new expression of freedom and higher national purposes. But this freedom and these purposes are to be democratic, voluntary, and shared-decidedly not the product of some monster-founder born by mating Machiavelli and Hobbes. Here, Dewey could only agree, and so, of course, would Oliver Wendell Holmes, Jr. and Roscoe Pound. This is perhaps the larger background to what Herbert Croly concluded in 1927:

If there are any abstract liberal principles, we do not know how to formulate them. . . Liberalism, as we understand it, is an activity. It is the effort to emancipate human life by means of the discovery and the realization of truth. But the truth only emerges as a function of individual and corporate life, and it needs for its vindication the subordination of principles to method. ${ }^{23}$

22. Adolph Berle, Jr. and Gardiner C. Means, The Modern Corporation and Private Property (New York: Macmillan, 1932); Adolph Berle, Jr., The 20th Century Capitalist Revolution (New York: Harcourt, Brace, 1954).

23. Croly quoted in Stettner, Shaping Modern Liberalism, p. 157, from The New Republic, March 2, 1927, p. 35. Stettner reminds the reader that the method Croly was calling for "is no longer pragmatic but religious." 
The issue raised by Eden's paper, however, is not whether he would also agree at this general a level (I suspect he might), but whether executive power and will-or even a powerful and autonomous national state-is the necessary deus ex machina to instantiate this kind of history and prophecy.

\section{EDEN'S SUBTERRANEAN NARRATIVE: SALVAIION AND DAMNATION IN AMERICAN POLITICAL THOUGHT}

Machiavelli by way of Hobbes (or Harvey Mansfield, Jr., by way of Thomas Pangle) is not a tenable framework within which to construct a narrative of American political thought. This narrative holds that the synthesis in the "Commonwealth Club Address" between a rights-based polity and a constitutionally unfettered presidency is proof of the Hobbesian-Machiavellian origins of modern liberalism and, perforce, America. But it is precisely this "perforce" which must be seriously questioned. If we are to read Alan Bloom or Thomas Pangle or Paul Rahe, this "perforce" is simply an noncontestable starting point. The Straussian narrative of European political thought then becomes an autopilot steering America through history toward the damnation deserved of those who committed the original Hobbesian sin. But if one turns instead to Harold Bloom or Perry Miller or Sacvan Berkovitch, or Bruce Kuklick or, indeed, to any serious histories of American literary culture and intellectual life, a rather different narrative structure is revealed, one with a much tighter fit with what we know of our political party and constitutional history.

Cryptically put, the "lost soul" of American politics was never lost. Civic virtue and democratic citizenship have always been an integral part of our intellectual, religious, and cultural life, always an integral part of our local and regional political life, and, periodically, a part of our national political life as well. This "lost soul" has taken many forms and has been written about in many different ways, most recently under the rubric of "civic republicanism." This "lost soul," this vision of America fulfilling its destiny to bring justice to the world, is rightly called by Dewey "the genuinely spiritual element of our tradition." He is merely expressing through pragmatism what was expressed in a slightly different vocabulary by churchmen and sociologists: "Democracy is more than a scheme of government. . . . Democracy is a great religious faith ... faith in man" even though America has not always been "conscious of the spirit which has possessed her." 24 Eden, in contrast, allusively and repeatedly (pp. 87, 88,

24. Lyman Abbott, The Rights of Man (Boston and New York: Houghton, Mifflin and Company, 1901), p. 196. Croly ends Progressive Democracy on this same note, contrasting "law" as external "works" with a living democratic "faith." Samuel Zane Batten, The New Citizenship: Christian Character in its Biblical Ideals, Sources, and Relations (Philadelphia: Union Press, 1898), pp. 253-4, expresses the same idea this way: "There are many indications that the great movement for human freedom and social justice, begun in the Reformation, is 
100) refers to an original or fundamental "liberal impulse," as if America had always unconsciously sought to return to Hobbes or to some other pathological form of democratic individualism which Tocqueville warned us about. But, as Tocqueville also showed, democratic community had always been an integral part of state constitutions, local political practices, public schools, and voluntary associational life generally. ${ }^{25}$ The limited and formal national Constitution was limited and formal precisely to protect the real centers of democratic life and politics in America, what communitarians today like to call "seedbeds of civic virtue." The national state (including its chief executive) was classically liberal because it was woefully weak without the voluntary and extra-constitutional support of other governments and institutions.

What Eden's study has suggested, but within a very different narrative structure, is that, given twentieth-century expectations placed on the national government, to "save" the Constitution in its limited and formal features seems to require a political executive exercising prerogative quite outside that Constitution. But certainly Jefferson's own description of the Louisiana Purchase is testimony to that same pattern. And as the Columbia University historian William Archibald Dunning had classically described, Lincoln, too, can be understood in these terms, riding roughshod around the Constitution through the exercise of military prerogative even while obeying the Constitution to the letter in its formal spheres. ${ }^{26}$ Wilson's reliance on voluntarism rather than official state power to mobilize the country for war represents this same phenomenon. We who have lived under the imperial presidency know well what it is like to live in these two worlds simultaneously. In the famous words of Theodore Lowi, "there is a Watergate of some kind everyday in the life of a president."27 But Lowi wants a constitutionalist or juridical answer-or at least a new kind of party system which would force the presidency back into something resembling the old constitutional forms. But so did the Democratic party in 1936:

We have sought and will continue to seek to meet these problems [which inevitably overflow State boundaries] through legislation within the Constitution. If these problems cannot be effectively solved by legislation within the Constitution, we shall seek such clarifying amendment as will assure to the legislatures of the several States and to the Congress of the United States, each within its proper jurisdiction, the power to enact those laws

\footnotetext{
about to take on new life and complete itself in what may be called the democracy of all life. . . For democracy . . . is less a form of government than a confession of faith; it is the confession of human brotherhood ... it is the recognition of common aims and common hopes. ..."

25. The issue has never been the existence of this vision or impulse, but its appropriate institutional locations and expressions and the relationship of the national government to those institutions-most notably today, the family.

26. William Archibald Dunning, Essays on the Civil War and Reconstruction (New York: Harper and Row, 1965, orig. 1897).
}

27. Lowi, The Personal President, p. 178. 
which the State and Federal legislatures, within their respective spheres, shall find necessary, in order adequately to regulate commerce, protect public health and safety and safeguard economic security. Thus we propose to maintain the letter and spirit of the Constitution. ${ }^{28}$

Neither Dewey nor Berle nor the progressives generally thought that this was possible or desirable. And given our political and constitutional history after 1936, is there any doubt that these constitutional niceties were jettisoned for good? But this is not new, not something that FDR first confronted. Most practicing political scientists in the 1930s and 1940s were raised on Charles Beard's textbook, American Government and Politics, first published in 1910 and published continuously through 1949. Here is what he taught those who taught us or taught our teachers:

No longer do statesmen spend weary days over finely spun theories about strict and liberal interpretations of the Constitution, about the sovereignty and reserved rights of states. No longer are men's affections so centered in their own commonwealths that they are willing to take up the sword . . . to defend state independence. It is true that there are still debates on such themes as federal encroachments on local liberties, and that admonitory volumes on "federal" usurpation come from the press. It is true also that conservative judges, dismayed at the radical policies reflected in new statutes, federal and state, sometimes set them aside in the name of strict interpretation. But one has only to compare the social and economic legislation of the last decade with that of the closing years of the nineteenth century, for instance, to understand how deep is the change in the minds of those who have occasion to examine and interpret the Constitution bequeathed to them by the Fathers. Imagine Jefferson . . . reading [Theodore] Roosevelt's autobiography affirming the doctrine that the President of the United States can do anything for the welfare of the people which is not forbidden by the Constitution! Imagine Chief Justice Taney . . . called upon to uphold a state law fixing the hours of all factory labor. . . . Imagine James Monroe . . . called upon to sign bills appropriating federal money for roads, education, public health ... and other social purposes! . . . Why multiply examples? ${ }^{29}$

28. Donald B. Johnson and Kirk H. Porter, National Party Platforms, 1840-1972 (Urbana: University of Illinois Press, 1975), p. $\mathbf{3 6 2 .}$

29. Charles Beard, American Government and Politics (New York: Macmillan, 1928), pp. 100-1. Note that all his 19th century examples are from the "democratic" party. He was equally complacent about justifications for protections for free speech: "It is a hard, cold proposition: by what process are we most likely to secure orderly and intelligent government. ... ?" Ibid., p. 36. His review of government control over speech, from the 1798 Sedition Act to sentencing a girl of twenty-one to fifteen years imprisonment "for taking part in issuing a circular severely attacking President Wilson's policy of intervention in Russia," is done without any questioning of the government's right to do so. Ibid., pp. 107-9. In his Economic Interpretation Beard has no kind words at all for the Antifederalist position and doesn't even mention their greatest contribution, the Bill of Rights. See Pope McCorkle, "The Historian as Intellectual: Charles Beard and the Constitution Reconsidered," American Journal of Legal History 28 (1984), pp. 333-4. Beard is equally dismissive of Jefferson's and Madison's Virginia and Kentucky Resolutions addressed against the Federalists-resolutions which became the founding documents of Jeffersonian Republicanism and Jacksonian Democracy. Charles Beard, "The Supreme Court-Usurper or Grantee?," Political Science Quarterly 27 (1912). 


\section{CONCLUSION}

For Beard and Dewey and Croly and, indeed, all of Berle's teachers, the purpose of law, including constitutional law, was not to found and maintain a regime by some primal (or bloody) act of abstract will, but to express and to expedite the substantive ideas of public good and social justice which free peoples generate through the agonistic struggles of democratic political life. This, indeed, is how James Bradley Thayer and Holmes saw the development of the common law and common-law methods of constitutional adjudication. And this is why they and their followers poured such scorn on "legal abstraction," "mechanical jurisprudence," and constitutional formalism. ${ }^{30}$ They were always happier with Marshall than with Taney, with Hamilton than with Jefferson, with Lincoln and the Republicans than with Jacksonian democracy. And, finally, this is why they and the progressives generally saw in rights-based liberalism and procedurally dominated political parties a conservative defense of extant lives and extant interests and therefore a barrier to reform and progress. (It is a wonder that today's feminists took so long to discover the possibilities of this way of thinking.) Perhaps now we, who can no longer clearly distinguish rights from entitlements and presidential authority from public opinion polls, must start over from where the early progressives began in order to rethink the appropriate spheres for rights and the appropriate place for citizenship and virtue. It is either that or the more sobering thought that our eighteenth-century constitution and our twentiethcentury plebiscitary president deserve each other.

30. Morton J. Horwitz, The Transformation of American Law, 1870-1960; The Crisis of Legal Orthodoxy (New York: Oxford University Press, 1992), chaps. 2, 4, and 7. 